Journal of Pharmacy Practice and Community Medicine.2018, 4(2):93-101• http://dx.doi.org/10.5530/jppcm.2018.2.22

e-ISSN: 2455-3255

\title{
The Evaluation of Pharmacy Strategic Plan in Past 2013-2016 and Forecasting of New Vision 2030 at Ministry of Health in Saudi Arabia
}

\author{
Yousef Ahmed Alomi ${ }^{1, *}$, Saeed Jamaan Alghamdi ${ }^{2}$, Radi Abdullah Alattyh ${ }^{2}$, Rasha Abdelsalam Elshenawy ${ }^{3}$ \\ ${ }^{1}$ The Past General Manager of General Administration of Pharmaceutical Care and Past Head, National Clinical pharmacy, \\ pharmacy practice and Pharmacy R and D Administration, Ministry of Health, Riyadh, KSA. \\ ${ }^{2}$ General Administration of Pharmaceutical Care, Ministry of Health, Riyadh, SAUDI ARABIA. \\ ${ }^{3}$ Ministry of Health, Riyadh, SAUDI ARABIA.
}

Received: 23 February 2018; Accepted: 11 May 2018

*Correspondence to:

Dr. Yousef Ahmed Alomi, The Past General Manager of General Administration of Pharmaceutical Care, Past Head, National Clinical pharmacy, and pharmacy practice, Past Head, Pharmacy R and $D$ Administration Ministry of Health, P.O.BOX 100, Riyadh 11392, Riyadh, SAUDI ARABIA. Email:yalomi@gmail.com

Copyright: (1) the author(s),publisher and licensee Indian Academy of Pharmacists. This is an open-access article distributed under the terms of the Creative Commons Attribution Non-Commercial License, which permits unrestricted non-commercial use, distribution, and reproduction in any medium, provided the original work is properly cited.

\begin{abstract}
Objective: To explore the outcomes of strategic plan implementations in past 2013-2016 and to update the pharmacy strategic plan based on new Saudi vision 2030. Method: It is a cross-sectional follow-up, monitor, and forecasting of General Administration of the pharmaceutical care strategic plan in 2016-2020. The authors review all six strategic plan, seventeen initiatives, and eighty-three projects. The Assessment from the baseline before applying the strategic plan 2013 to 2016 at MOH hospitals and primary care centers. The new updating of a strategic plan based new vision of Ministry of Health and Saudi vision 2030 and correlate with them accordingly. Results: The total project of past strategic plan was 84 projects. The total number of fully implemented projects were at hospital 29 (34.5\%) projects, and primary care centers were $19(22.6 \%)$ projects. The total number of some implemented programs at the hospital was 28 (33.33\%) while at primary care centers were $26(30.95 \%)$ projects. The total number not implemented at hospitals were 25 ( $29.76 \%)$ while at primary care centers were 36 ( $42.85 \%)$. The total number of new projects added to the new plan was seven, and a total number of deleted projects was one. The total number of projects with new strategic plan vision 2030 were ninety projects. Conclusion: The last pharmacy strategic plan at Ministry of Health organization was beneficial during 2013-2016. Several programs implemented for the first time. That is including but not limited to stewardship of antimicrobial program, pain management program, and medication safety program. The new updating pharmacy strategic plan compatible and support the Ministry of Health and Kingdom of Saudi Arabia new strategic plan with new vision 2030.
\end{abstract}

Key words: Pharmacy, Strategic plan, Forecasting, Vision 2030, Ministry of Health, Saudi Arabia.

\section{INTRODUCTION}

General administration of Pharmaceutical care started new pharmacy plan 2012-2022 in early 2013..$^{[1]}$ The plan consisted of six strategic goals, seventeen initiatives, and eighty-three projects. The executive plan for each year initiated for each initiative and projects. Some project divided into several years and others for year applications. The General administration of pharmaceutical care setup strategies for each project. Each project assessed demand and needs based on some patient diseases, geographical area of disease, the meet Saudi Central Board for Accreditation of Healthcare Institutions (CBAHI) standard and Joint commission of hospital accreditation standards, available of pharmacy human resources, burden of drug-related problems, and burden of PharmacoEconomic issues. The general manager of pharmaceutical care formulated a central committee of this project headed by him and assisted by clinical pharmacist specializing in the project area. The committee consisted represented of twenty regions if the pharmacist is available. The plan for each project set up by the first meeting. Quality management indicators for each project stated. The represented pharmacist went to the region to implement this project with coordination of pharmaceutical care directorate in the region. The coordinator pharmacist of the committee followed up with all representatives for implementation and sent a monthly report to the general manager of general administration of pharmaceutical care at Ministry of Health $(\mathrm{MOH}) \cdot{ }^{[2-3]}$ All success stories start with a vision, and strong visions based on active initiates, and projects. A vision statement is an aspirational statement of where want to be in the future. It should set the overall direction for the organizations and teams. Moreover, it needs to be bold and inspirational. The authors used several tools to follow up the implantation of the strategic plan. This plan needs to review annually and forecasting every three to four years. In late 2016, The Kingdom of Saudi Arabia launched the "Saudi Arabia's Vision for 2030" with a strategic plan in the next upcoming fifteen years. ${ }^{[4-5]}$ It started delivering the overarching plans and projects that needed to be set out. There are several literatures discussed of follow up and forecasting of pharmacy strategic plan for instant American Society of Health-System Pharmacist (ASHP). ${ }^{[6-9]}$ They had system to follow up and forecasting their pharmacy strategic plan, for each parameter they measure the real situation and forecasting of the future. The authors not familiar with any publication to discussed pharmacy strategic plan and forecasting in Saudi Arabia or gulf and Middle East counties. The aim of the study to explore the results of implementations of strategic plan in past 2013-2016 and updating the pharmacy strategic plan based on new Saudi vision 2030. 


\section{Alomi, et al:: Study about strategic plan for Saudi new vision}

\section{METHOD}

It is a cross-sectional follow-up, monitor, and forecasting of General Administration of the pharmaceutical care strategic plan in 2016-2020. The authors review all six strategic plan, seventeen initiatives, and eighty-three projects. The Assessment from the baseline before applying the strategic plan 2013 to 2016 at MOH hospitals and primary care centers. In addition to privates sectors. The authors revived annual reports from each committee explained the stages of implementation. The new updating of a strategic plan based new vision of Ministry of Health and Saudi vision 2030 and correlate with them accordingly.

\section{RESULTS}

The total project of past strategic plan was eighty-four projects. The total number of fully implemented projects were at hospital 29 (34.5\%) projects, and primary care centers were $19(22.6 \%)$ projects. The total number of some implemented programs at the hospital was $28(33.33 \%)$ while at primary care centers were $26(30.95 \%)$ projects. The total number not implemented at hospitals were $25(29.76 \%)$ while at primary care centers were $36(42.85 \%)$. The total number of new projects added to the new plan was seven, and total number of deleted projects was one. The total number of projects with new strategic plan vision 2030 were ninety projects. The total projects of the 1st strategic goal were 35 projects. The number of projected implemented at the hospitals were $18(51.4 \%)$ projects, the number of projects with some implementation were $8(22.85 \%)$ projects, and $9(25.14 \%)$ projects not implemented. While in the primary care centers showed the number of projected implemented were $10(28.57 \%)$ projects, the number of projects with some implementation were $8(22.85 \%)$ projects, and $17(48.57 \%)$ projects not implemented. In the private sectors all of the projects $35(100 \%)$ not implemented. With new vision 2030 all projects suggested to continue expect one project related to network of drug information centers as showed in Table 1. The total of project of the 2 nd strategic goal were 24 projects. The number of projected implemented at the hospitals were $4(17.4 \%)$ projects, the number of projects with some implementation were 10 (43.47\%) projects, and $8(34.78 \%)$ projects not implemented. While in the primary care centers showed the number of projected implemented were $4(17.4 \%)$ projects, the number of projects with some implementation were 10 (43.47\%) projects, and $9(41.6 \%)$ projects not implemented. In the private sectors all of the projects $23(100 \%)$ not implemented. With new vision 2030 all projects suggested continuing with additional one project related to multidisciplinary research of pharmaceutical care as shown in Table 4.

The total of the project of the $3 \mathrm{rd}$. Strategic goal was eight projects. The number of projected implemented at the hospitals were $0(0 \%)$ projects, the number of projects with some implementation was $2(25 \%)$ projects, and 6 $(75 \%)$ projects not implemented. While in the primary care centers showed the number of projected implemented were $2(33.33 \%)$ projects, the number of projects with some implementation were $1(16.66 \%)$ projects, and $3(50 \%)$ projects not implemented as showed in Table 7. In the private sectors all of the projects $8(100 \%)$ not implemented. With new vision 2030, all projects suggested continuing with additional three new projects related to printed patient counseling materials, national formulary connected with health insurance, and tele-pharmacy and telemedicine system as shown in Table 5. The total of the project of the $4^{\text {th }}$ strategic goal was 11 projects. The number of projected implemented at the hospitals were $5(45.45 \%)$ projects, the number of projects with some implementation was 5 (45.45\%) projects, and $1(9.1 \%)$ projects not implemented. While in the primary care centers showed the number of projected implemented were $5(45.45 \%)$ projects, the number of projects with some implementation were $5(45.45 \%)$ projects, and $1(9.1 \%)$ projects not implemented. In the private sectors all of the projects $11(100 \%)$ not implemented. With new vision 2030, all projects suggested continuing as shown in Table 6 . The total of the project of the $5^{\text {th }}$ strategic goal was seven projects. The number of projected implemented at the hospitals were $2(33.33 \%)$ projects, the number of projects with some implementation was $3(50 \%)$ projects, and $1(16.66 \%)$ projects not implemented. While in the primary care centers showed the number of projected implemented were $2(33.33 \%)$ projects, the number of projects with some implementation were $1(16.66 \%)$ projects, and $3(50 \%)$ projects not implemented. In the private sectors all of the projects $6(100 \%)$ not implemented. With new vision 2030 , all projects suggested continuing with additional three new projects related to exchange system of medications, the business model of pharmacy projects, and clinical trial from pharmaceutical companies as shown in Table 5.

\section{DISCUSSION}

In the strategic goal number one with Pharmacy practice programs as follows; the general standard of hospital building with pharmacy equipment's, medical furniture, and nonmedical furniture and according to bed capacities released and distributed overall hospital pharmacies and primary care pharmacists. ${ }^{[2]}$ A number of TPN services in 24 hospitals in 2012 increase to 52 hospitals 2016. ${ }^{[10]}$ The Intravenous Admixture design established based on 797 United States standards, and a number of new IV room founded at 28 hospitals. In the clinical pharmacy programs; the Number of drug information services ten hospitals increased to 48 hospitals. ${ }^{[3,11]}$ The number hospital had Antimicrobial stewardship program in 2013 zero hospitals to 40 hospitals in 2016. ${ }^{[12]}$ The number of the hospital had pain management program from zero hospitals to 20 hospitals. ${ }^{[13]}$ The number of hospitals had an Anticoagulation program from none hospital in 2013 to 10 hospitals had this program. One of the famous and comprehensive programs was medication safety program; it covered twenty regions with more than two hundred hospitals. The incident of drug-related mortality decrease from fifteen cases within 2012 to zero cases in 2015. ${ }^{[14-15]}$ New pharmacy practice program implements at Ministry of Health hospital like Ramadan Pharmaceutical care, Mass gathering of pharmaceutical care. ${ }^{[16-17]}$ In The strategic goal number two with the Pharmacy human resources goal. The hospital pharmacy recruitment stranded changed from 0.04 pharmacist per bed to 0.2 pharmacists per bed with five fold increases. The number of clinical pharmacists increased tenfold. ${ }^{[18]}$ The primary care pharmacy recruitment stranded changed from one pharmacist to three pharmacists and one clinical pharmacist based on primary care center type. ${ }^{[19]}$ Patient satisfaction with pharmacy services is not existed in 2013. The hospital and primary care pharmacies applied this system in 2014 with results of scoring average four for three primary care centers pharmacies as pilot studies published in elsewhere. ${ }^{[20]}$ In the strategic goal number three with Pharmacy informatics and automation; the number of hospitals had computerized physician order enter ten in 2013 then increase to 45 hospitals in 2016. The pharmacy automation existed in ten hospitals in 2013 then increased to 20 hospitals. ${ }^{[2]}$ In the strategic goal number four with the Pharmacy culture the Patient medication counseling program not existed in 2013. The complete proposal and system with a memo sent to twenty-one region to apply this program. ${ }^{[2]}$ In the strategic goal number five, several programs measured the economic impact and cost burden of the pharmacy practice program for instant medication safety and drug information services. ${ }^{[11,21-22]}$

\section{CONCLUSION}

One-third of the updated pharmacy strategic plan implemented during the past four years at Ministry of Health hospitals and primary care centers. Several new pharmacy administration and pharmacy practice implemented. The new pharmacy strategic plan with vision 2030, will cover all governmental and private sectors with new cost-efficiency and best utilization projects and programs. 


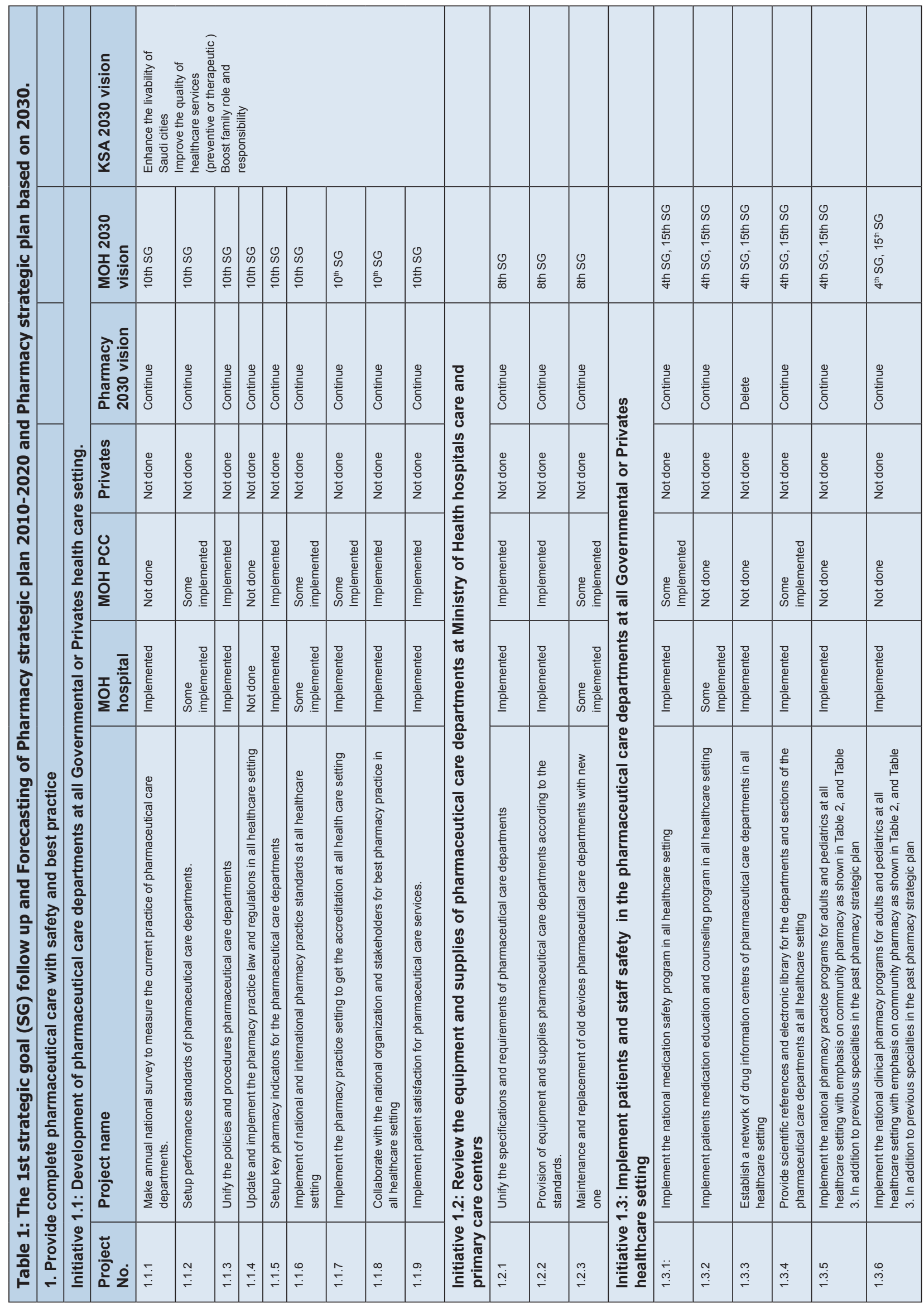




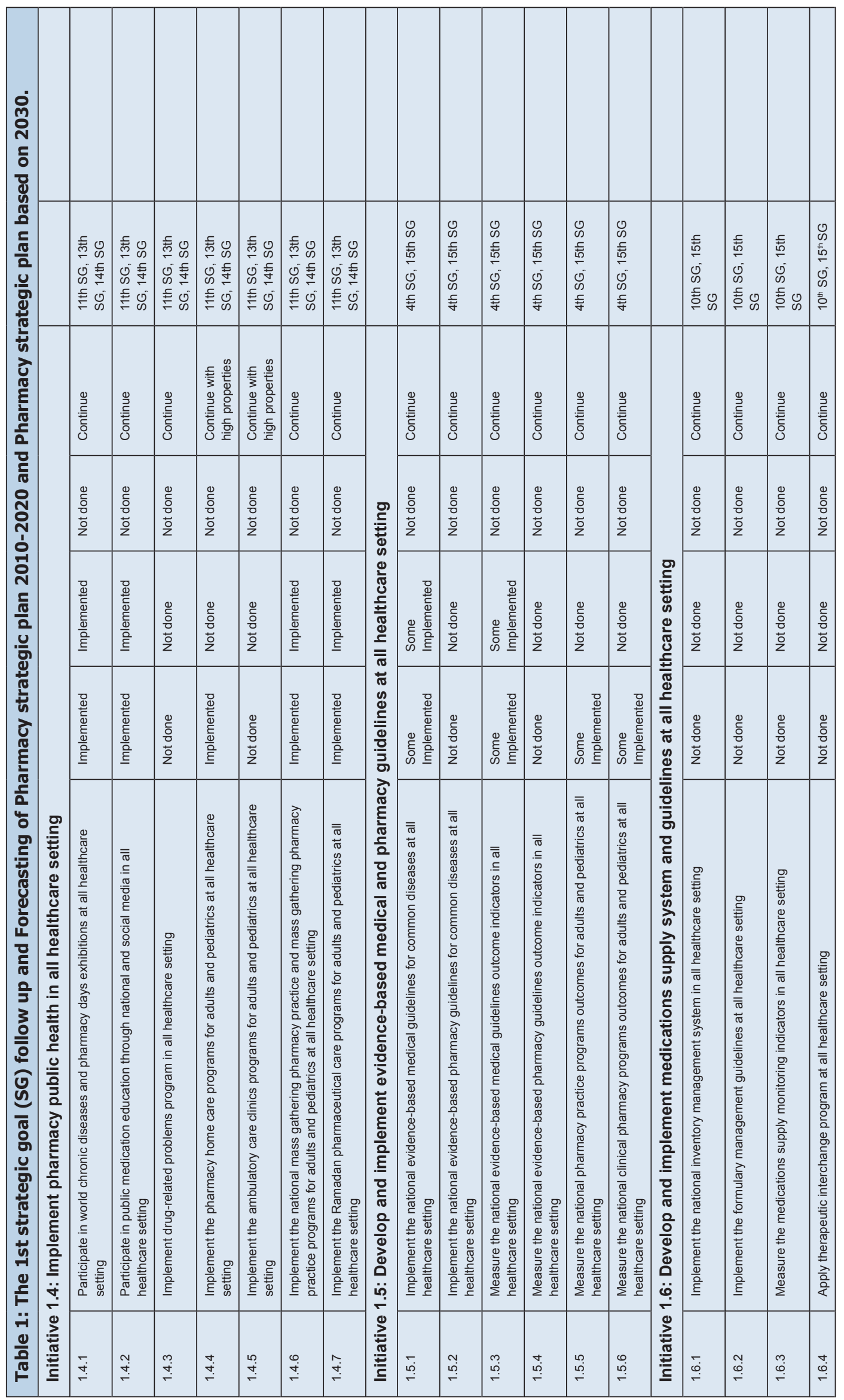


Table 2: Some examples of national community pharmacy practise and community pharmacy programs for adults and pediatrics.

\begin{tabular}{|c|c|c|}
\hline Program & Community Pharmacy Practice & Community Clinical Pharmacy \\
\hline Adults & $\begin{array}{l}\text { Adults MTM Ambulatory Care Pharmacy } \\
\text { Adults Clinical compounding } \\
\text { Adults Community Pharmacy Informatics } \\
\text { Adults Community Pharmacy Human Resources } \\
\text { Adults Community Medical and Pharmacy Education } \\
\text { Adults Community Pharmacy Public Health }\end{array}$ & $\begin{array}{l}\text { Community Adult General Medicine } \\
\text { Community General Pediatrics } \\
\text { Community General Psychiatry } \\
\text { Community General Family Medicine } \\
\text { Community General Dental Therapy and oral medicine } \\
\text { Managed Care Community Pharmacy } \\
\text { Community Adult General Medicine } \\
\text { Community Adults Cardiology } \\
\text { Community Adults Nephrology } \\
\text { Community Adults Infectious Diseases } \\
\text { Community Adults Endocrinology\& Metabolism } \\
\text { Community Adult Pulmonary Diseases } \\
\text { Community Adult Hematology and Anticoagulation } \\
\text { Community Adult Oncology } \\
\text { Community Adult Drug Utilization Evaluation } \\
\text { Community Adult Drug Information } \\
\text { Community Adult Medication Safety } \\
\text { Community Adults Pharmacoeconomics } \\
\text { Community Adults Psychiatry } \\
\text { Community Adult Dental Therapy and oral medicine } \\
\text { Community Adults Organ Transplant } \\
\text { Community Adults Pharmacogenomics } \\
\text { Community General Psychiatry } \\
\text { Community Child / Adolescent Psychiatry } \\
\text { Community Addiction Medicine } \\
\text { Community Geriatric Psychiatry } \\
\text { Community Adults Psychiatry } \\
\text { Community General Family Medicine } \\
\text { Community Pharmacy Public Health } \\
\text { Community Geriatric Medicine } \\
\text { Community Pharmacy Home Health Care } \\
\text { Community Mass Gathering Pharmaceutical Care }\end{array}$ \\
\hline Pediatrics & $\begin{array}{l}\text { Pediatrics MTM Ambulatory Care Pharmacy } \\
\text { Community Pediatrics Clinical compounding } \\
\text { Community Pediatric Oncology Preparation } \\
\text { Community Pediatrics Pharmacy Informatics } \\
\text { Community Pediatrics Pharmacy Human Resources } \\
\text { Community Pediatrics Medical and Pharmacy Education } \\
\text { Community Pediatrics Pharmacy Public Health }\end{array}$ & $\begin{array}{l}\text { Community General Pediatrics: } \\
\text { Community Pediatrics Endocrinology } \\
\text { Community Pediatrics Nephrology } \\
\text { Community Pediatrics Hematology and Anticoagulation } \\
\text { Community Pediatrics Oncology } \\
\text { Community Pediatrics Infectious Diseases } \\
\text { Community Pediatrics Pulmonary Diseases } \\
\text { Community Pediatrics Cardiology } \\
\text { Community Pediatrics Drug Utilization Evaluation } \\
\text { Community Pediatrics Drug Information } \\
\text { Community Pediatrics Medication Safety } \\
\text { Community Pediatrics Pharmacoeconomics } \\
\text { Community Pediatrics Dental Therapy and oral medicine } \\
\text { Community Pediatrics Organ Transplant } \\
\text { Community Pediatric Pain Management } \\
\text { Community Pediatrics Pharmacogenomics }\end{array}$ \\
\hline
\end{tabular}

Table 3: Some examples of Community ambulatory care clinics for adults and pediatrics.

\begin{tabular}{|l|l|l|}
\hline Program & Community Ambulatory care clinics for adults & Community Ambulatory care clinics for pediatrics \\
\hline Adults & Community Adults Cardiology Clinics & Community Pediatrics Endocrinology Clinics \\
& Community Adults Nephrology Clinics & Community Pediatrics Nephrology Clinics \\
& Community Adults Infectious Diseases Clinics & Community Pediatrics Hematology and Anticoagulation Clinics \\
& Community Adults Endocrinology \& Metabolism Clinics & Community Pediatrics Oncology Clinics \\
& Community Adult Pulmonary Diseases Clinics & Community Pediatrics Infectious Diseases Clinics \\
& Community Adult Hematology and Anticoagulation Clinics & Community Pediatrics Pharmacy Infection Control Clinics \\
& Community Adult Oncology Clinics & Community Pediatrics Pulmonary Diseases Clinics \\
& Community Adult Patient Medication Education Clinics & Community Pediatrics Cardiology Clinics \\
& Community Addiction Medicine Clinics & Community Pediatrics Patient Medication Education Clinics \\
& Community Adults Psychiatry Clinics & Community Pediatrics Organ Transplant Clinics \\
& Community Adults Organ Transplant Clinics & Community Pediatrics Endocrinology\& Metabolism Clinics \\
& Community Adults HIV Clinics & Community Pediatrics Psychiatry Clinics \\
& Community Adults Hepatology Clinics & Community Pediatrics Family Medicine Clinics \\
& Community Adults Family Medicine Clinics & \\
& Community Geriatric Psychiatry Clinics & \\
Community Adults Pain Management Clinics & \\
\hline
\end{tabular}




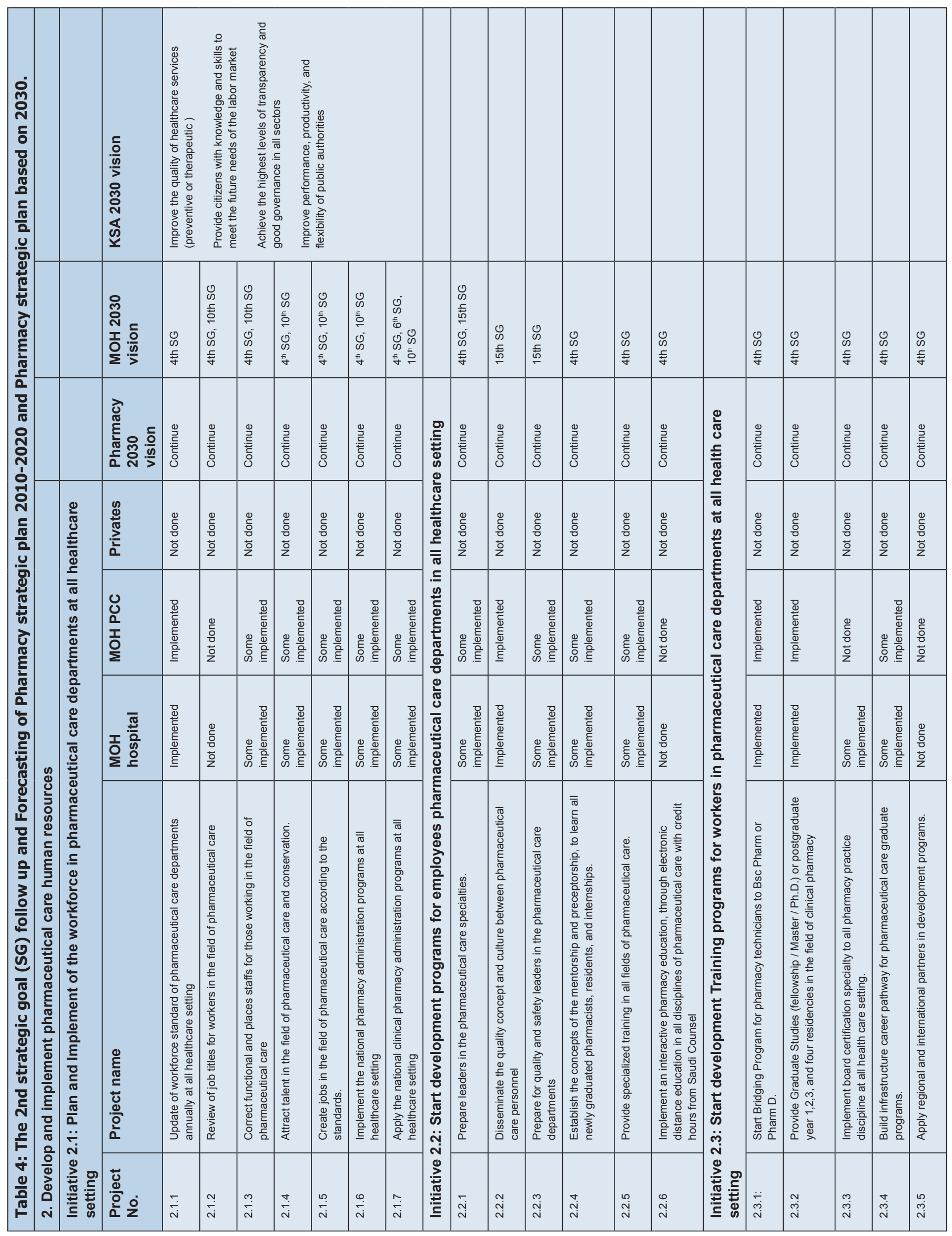



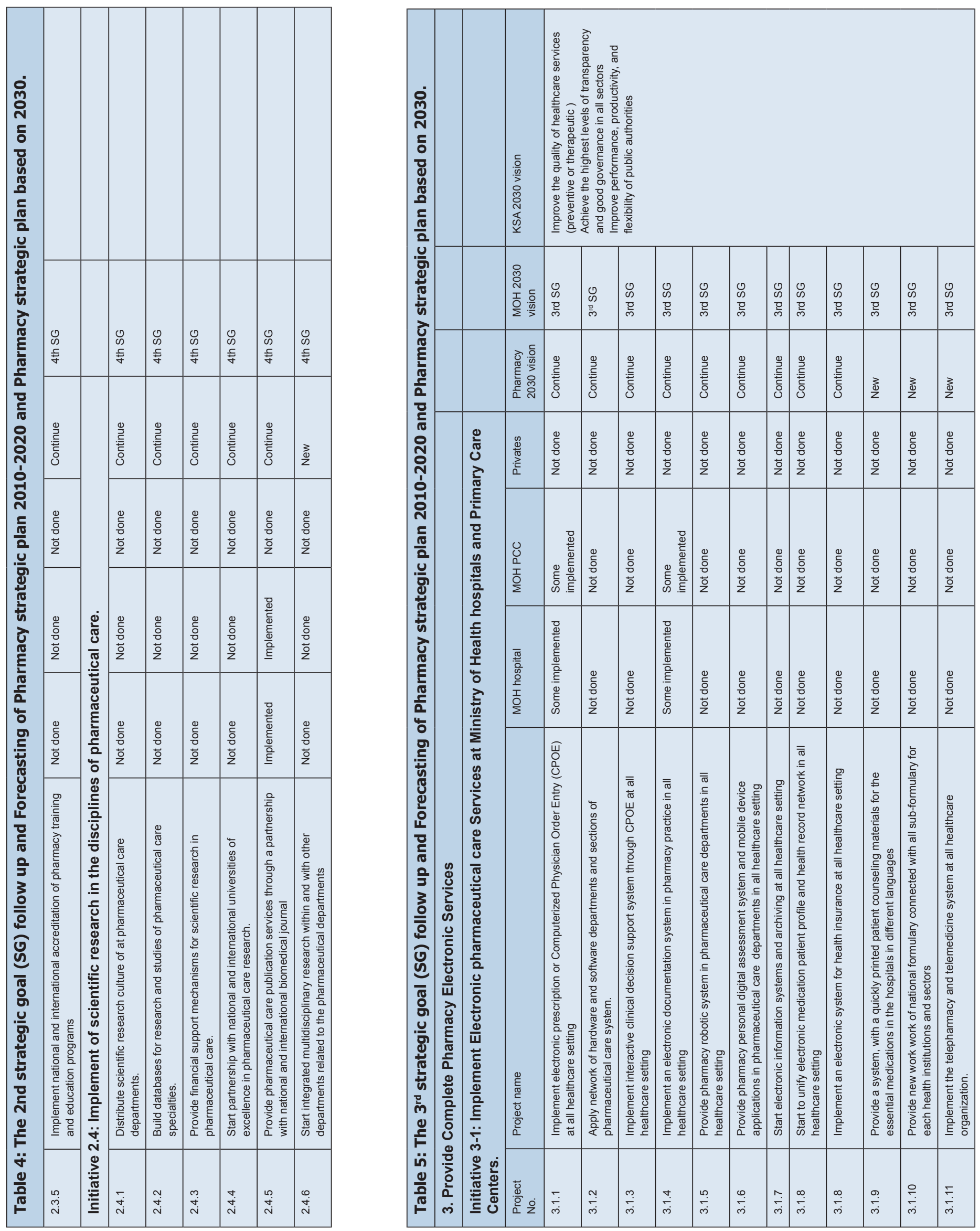


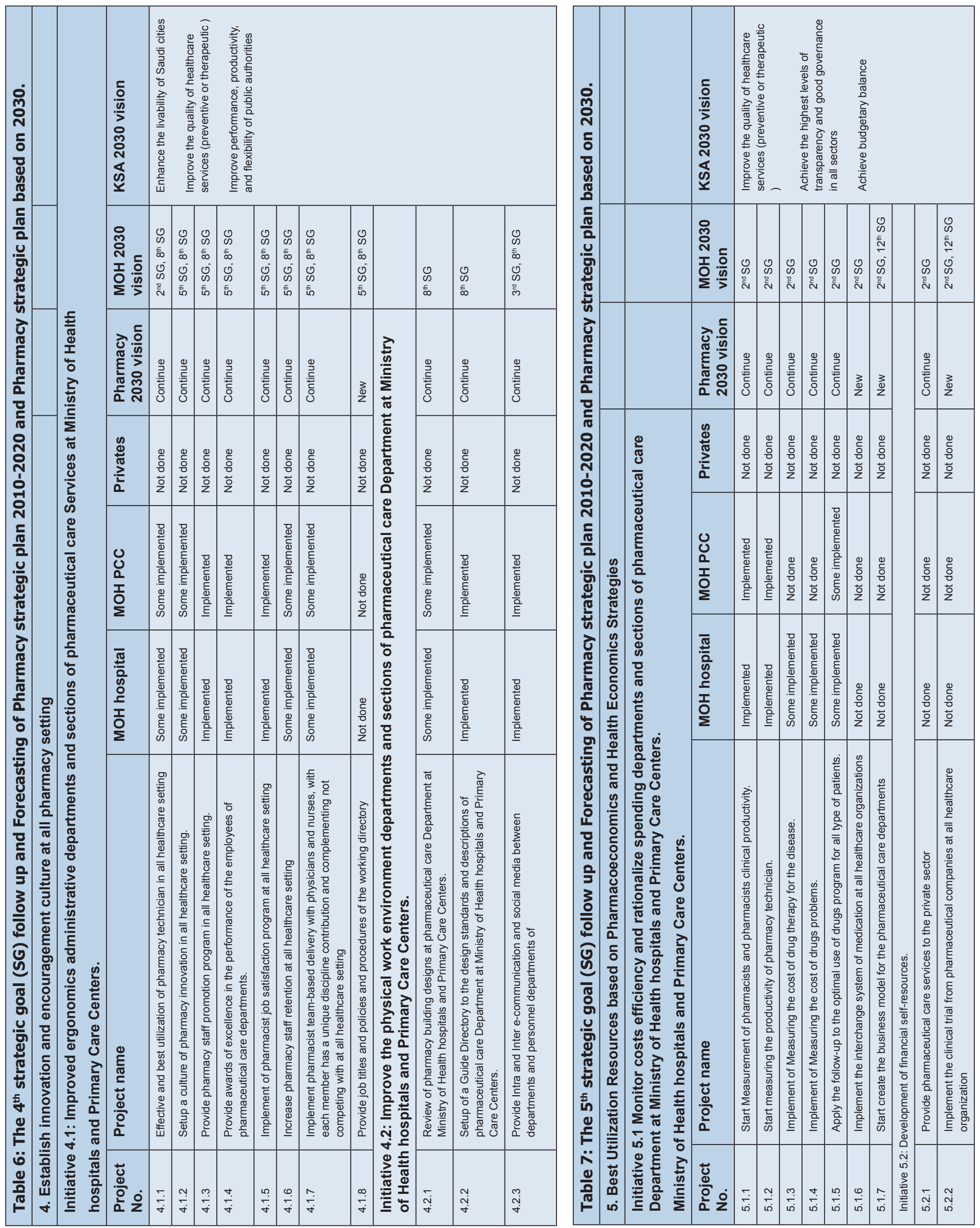




\section{ACKNOWLEDGMENT}

None.

\section{CONFLICT OF INTEREST}

None.

\section{ABBREVIATIONS}

KSA: Kingdom of Saudi Arabia; ASHP: American Society of Health-System Pharmacist; MOH: Ministry of Health; USA: United States of America.

\section{REFERENCES}

1. Alomi YA, Alghamdi SJ, Alattyh RA. Strategic Plan of General Administration of Pharmaceutical Care at Ministry of Health in Saudi Arabia 2012 - 2022. JPharm Pharm Scien. 2015;1(13):1-8.

2. Alomi Y. National Pharmacy Administration Programs. BAOJ Pharm Sci. 2015;1(2):1-2.

3. Ahmed Y, Pharm A, Pharm C. National Pharmacy Practice Programs at Ministry of Health in Saudi Arabia. 2015;1(2):17-8.

4. Government of Saudi Arabia. Saudi Arabia Vision 2030. 2016.

5. Saudi Arabia's Vision 2030. National Transformation Program 2020. 2017.

6. Zellmer WA, Walling RS. Pharmacy Forecast 2013-2017: Strategic planning advice for pharmacy departments in hospitals and health systems. Am J Heal Pharm [Internet]. 2012;69(23):2083-7.

7. ASHP Research and Education Foundation. Pharmacy Forecast 2015-2019: Strategic Planning Advice. 2015. https://pdfs.semanticscholar.org/8c31/9398d 892eece4b74998838cea807391ce98f.pdf

8. Zellmer W. Pharmacy Forecast 2016-2020. Strategic Planning Advice for Pharmacy Departments in Hospitals and Health Systems. Bethesda, Maryland: ASHP. 2016

9. Allen SJ, Zellmer WA, Knoer SJ, Phelps PK, Marvin KC, Pulvermacher A, et al. ASHP Foundation Pharmacy Forecast 2017: Strategic Planning Advice for Pharmacy Departments in Hospitals and Health Systems. Am J Health Syst Pharm. 2017;74(2):27-53.
10. Alomi YA, Aljudaibi SM. National Survey of Total Parenteral Nutrition Practice in Saudi Arabia: Dispensing and Administration at $\mathrm{MOH}$ Hospitals. EC Nutr. 2016;3(6):748-56.

11. Alomi YA, Almudaineem HY, Alarnous T, Alshurei S, Alsharafa A, Alzahrani T, et al. Cost-Efficiency of National Drug Information Center Through Ministry of Health Hotline Calling Services (937) in Saudi Arabia: Application of a Mercian Model. Value Heal J Int Soc Pharmacoeconomics Outcomes Res. 2015;18(7):A735.

12. Alomi YA. National Antimicrobial Stewardship Program in Saudi Arabia; Initiative and the Future.

13. Alomi YA. National Pharmacy Pain Management Program at Ministry of Health in Saudi Arabia. J Pharmacol Clin Res. 2017;3(2).

14. Alomi YA. National Medication Safety Program at Ministry of Health in Saudi Arabia. J Pharmacovigil. 2015;3:e145.

15. Alomi YA, Kamal E, Alomi, Kamal, Pharmacovigilance. National Drug Quality Reporting System at Ministry of Health in Saudi Arabia. J Pharmacovigil. 2016;4(208):2

16. Alomi YA. National Mass Gathering Pharmaceutical Care Program at $\mathrm{MOH}$ in Saudi Arabia. J Pharm Pract Community Med. 2016;2(3).

17. Alomi YA, Zahran R. Self-Assessment of mass gathering (Hajj) pharmaceutical care program in Saudi Arabia. J Pharm Pract Community Med. 2016;2(24):137-43.

18. Ahmed Alomi Y, Pharm B, Clin Pharm M. A new Guidelines on Hospital Pharmacy Manpower in Saudi Arabia. J Pharm Pract Community Med. 2016;2(22):30-1.

19. Alomi YA. Primary Care Center Pharmacy Manpower New Guidelines in Saudi Arabia. J Pharmacol Clin Res. 2016;1(1).

20. Alomi YA, Kurdy L, Aljarad Z, Basudan H, Almekwar B, Almahmood S. Patient satisfaction of pharmaceutical care of primary care centers at Ministry of Health in Saudi Arabia. J Pharm Pract Community Med. 2016;2(23):79-87.

21. Alomi YA, Alanazi AA, Alsallouk SA, Almaznai MM, Abu-Alnaja NI, Alduhilan M, et al. Cost-Efficiency Of Medication Safety Program At Pediatrics, Obstetrics, And Gynecology Hospital, East Province, Saudi Arabia. Value Heal. 2016;19(7):A464.

22. Alomi YA, Al-Shubbar NA, Lubad NA. Economics outcomes of medication safety program at public hospital in Riyadh, Saudi Arabia. In: Value in Health. 2017;20(5)A32-A32.

Cite this article as: Alomi YA, Alghamdi SJ, Alattyh RA, Elshenawy RA. The Evaluation of Pharmacy Strategic Plan in Past 2013-2016 and Forecasting of New Vision 2030 at Ministry of Health in Saudi Arabia. J Pharm Pract Community Med. 2018;4(2):93-101. 